\title{
Article \\ Culture-Led Plan for Peri-Urban Agricultural Sustainability: A Case of Pu'an Village in China
}

\author{
Wei Li ${ }^{1,2}$, Yang Zhou ${ }^{3, *}$ and Zhanwei Zhang ${ }^{4}$ \\ 1 School of Geography and Planning, Sun Yat-sen University, Guangzhou 510275, China; \\ liwei289@mail.sysu.edu.cn \\ 2 Southern Marine Science and Engineering Guangdong Laboratory (Zhuhai), Zhuhai 519000, China \\ 3 Department of Architecture and Urban Planning, Institute of Urban Planning and Design, Nanjing University, \\ Nanjing 210093, China \\ 4 Chinese Academy of Social Sciences, Guangzhou 510000, China; zhzhanw2@mail3.sysu.edu.cn \\ * Correspondence: dg1636011@smail.nju.edu.cn
}

Citation: Li, W.; Zhou, Y.; Zhang, Z. Culture-Led Plan for Peri-Urban Agricultural Sustainability: A Case of Pu'an Village in China. Land 2021, 10, 242. https://doi.org/10.3390/ land10030242

Academic Editors: Roberto Henke and Francesco Vanni

Received: 29 January 2021

Accepted: 24 February 2021

Published: 1 March 2021

Publisher's Note: MDPI stays neutral with regard to jurisdictional claims in published maps and institutional affiliations.

Copyright: (c) 2021 by the authors. Licensee MDPI, Basel, Switzerland. This article is an open access article distributed under the terms and conditions of the Creative Commons Attribution (CC BY) license (https:// creativecommons.org/licenses/by/ $4.0 /)$.

\begin{abstract}
Most cases of multifunctional peri-urban agriculture offer diverse economic and ecological benefits, while a few involve cultural dimensions. In China, a "cultural turn" in the construction plan of beautiful villages has occurred. Through the analysis of policy and focus-group interviews, this research analyzes a case study of rural planning in the Pu'an village, a peri-urban village near Changzhou city in the Yangtze River Delta, China. Particular attention is given to investigating the process of identifying the local cultural symbol of a multifunctional plant, the bulrush. Combining natural landscape and cultural resources, rural planning explores the multifunctional agricultural services based on the bulrush-central creative industry in Pu'an village. The research introduces the framework of "bulrush + creative industry," which includes one core industry and two extended industries. The core industry is a creative processing industry, and the two extended ones are the creative planting industry and the creative tourist industry. Highlighting the participation of local villagers and outsiders or urban tourist, as well as the creative class and entrepreneurs, the research emphasizes the revival of local rural culture, especially in peri-urban villages. Finally, this paper contributes to exploring a new area of cultural dynamics for the sustainable development of peri-urban agriculture, combined with creative rural experience and ruralism.
\end{abstract}

Keywords: cultural dynamics; multifunctional agriculture; peri-urban sustainability; plan

\section{Introduction}

Peri-urban villages are faced with the pressures of urbanization and the need to preserve agriculture [1]. Though urbanization changes the peri-urban landscape significantly, agriculture is still important to protect "green" spaces for rural and urban life [2,3]. With the diversified demands of economic, social, and ecological development, a high degree of agricultural diversification is commonly acknowledged in peri-urban rural planning [4-8]. Scholars have found that plans for peri-urban agriculture (PUA) in sub-Saharan Africa, the Middle East and North Africa pay more attention to market-oriented agricultural production, food security, and ecosystem protection $[9,10]$, while in North America and Europe, the focus is more on nonagricultural diversification, including energy production, agritourist activities, on-farm processing, and direct sales activities [11,12]. However, aside from the economic and ecological benefits of multifunctional PUA, there are also some cultural dimensions $[13,14]$.

In China, a "cultural turn" in rural planning has occurred, which has encouraged cultural construction in villages in coordination with ecological protection. In 2013, the central government put forward the idea of "promoting the construction of rural ecological civilization, and striving to build beautiful villages" [15]. Guided by this idea, the construction project of "Beautiful Villages" (in Chinese: "Zhongguo meili xiangcun"), one of 
the most important components of the "Beautiful China" concept, aims to develop and enhance production, improve standards of living and rural civilization, create a clean and tidy environment, and promote democratic management $[16,17]$. In the new era, rural cultural inheritance and rejuvenation have become increasingly important in creating a civilized society in villages. In addition, agriculture could be considered as an integral part of the cultural landscape in densely urbanized areas, in terms of evoking nostalgia or homesickness $[18,19]$. Therefore, faced with rapid urbanization and advanced modernization, it is essential and urgent for rural planners to construct a guideline for nurturing rural culture and customs in peri-urban villages.

The creative industry, as a special cultural industry, developed in postindustrial cities, and has gradually transferred to rural villages $[20,21]$. Some practices in foreign villages have provided references for developing a creative countryside [22,23]. Although when compared to the urban context the policies in rural areas remain limited [24,25], they still cover the three categories of developing specific creative sectors [24-26], nurturing the rural creative class [27-30], and improving creative capacity or cultural vitality [31-33]. In the current research, we have found that identifying local cultural resources and "listening to locals" should be the basic principles in policymaking. With the diversified demands of locals, the policy needs to consider the potential integration of cultural production and other sectors into rural planning for sustainable development [34]. Peri-urban villages in particular, which are complex and exhibit diverse urban-rural linkages, need a more rigorous and nuanced guideline. Against the emerging mixed framework of the creative industry, our research has tried to provide a flexible and practical plan for fostering integration between the creative industry and the sustainability of agriculture in periurban villages.

The rural plan of the Pu'an village is a typical case, labeled a "culturally led" plan to develop the multifunctional integration of agriculture and the creative industry. Pu'an village is located in the suburban area of Changzhou city, displaying a large amount of green space and wetlands. Although the village originally had a pleasant ecological environment with an advantageous location in terms of transportation, agriculture developed slowly. The output value of crops was quite low, and has failed to produce special local agricultural products in the past two decades. Against this background, the research illustrated the process and framework of the new culture-led rural plan in terms of agricultural development, which has helped establish the agenda for the sustainable transitions demanded in building a beautiful village in Pu'an. The main research questions are as follows:

1. How do we define a cultural symbol, as connected to agricultural development in a rural creative industry?

2. How do we plan the mixed framework required for culture-oriented multi-industries to use local resources in a sustainable way?

The structure of the research is as follows. By illustrating the features of Pu'an village and our methodology, we explored the process of defining the bulrush as a rural cultural symbol in rural planning. Additionally, we revealed the designed framework of "bulrush + creative industry." This research contributes to the investigation of the cultural dimensions of PUA, and explores the process and framework of culture-led rural planning in a periurban village.

\section{Materials and Methods}

\subsection{Study Area}

$\mathrm{Pu}^{\prime}$ an village is located in the north of Lijia town, and belongs to Wujin district, Changzhou city. The peri-urban village has an advantageous location in terms of transportation, and it takes 10-15 min of driving to reach the central area in the Wujin district (Figure 1). Residents in the Wujin district have strong consumption tendencies. Pu'an village also has comparatively advantageous natural environmental and resource conditions. It occupies $4.14 \mathrm{~km}^{2}$ land, of which $72.29 \%$ is nonconstruction area. Among the nonconstruction area, $53.62 \%$ is assigned to agriculture and forestry, while $18.67 \%$ is a 
water area (Table 1). With 984 households and nearly 4000 people, the per capita living area is $133.54 \mathrm{~m}^{2}$ / person. According to the land-use plan, the main land-use criterion in Pu'an village is ecological protection, and some is set aside for industrial construction. However, in 2016, the output value of agriculture was less than CNY 10 million, which placed it third from the bottom out of the 14 villages in the town.

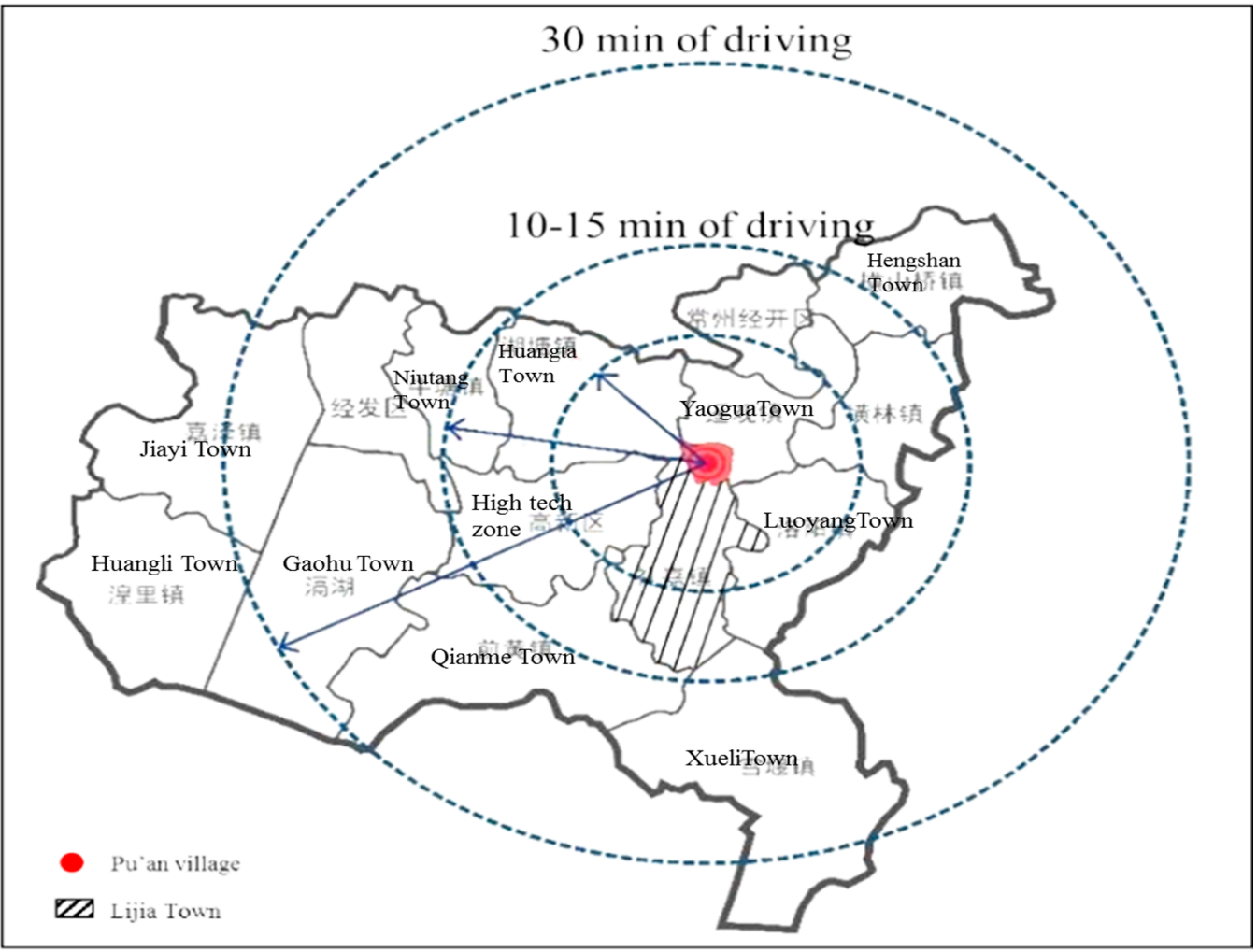

Figure 1. Location of Pu'an village in Wujin district, Changzhou city.

Table 1. Land use in Pu'an village in 2016.

\begin{tabular}{|c|c|c|}
\hline Land-Use Type & Land Area $\left(\mathrm{hm}^{2}\right)$ & $\begin{array}{l}\text { Proportion of Urban } \\
\text { and Rural Land (\%) }\end{array}$ \\
\hline Construction land & 114.74 & 27.71 \\
\hline Non-construction land & 299.26 & 72.29 \\
\hline Watershed & 77.28 & 18.67 \\
\hline $\begin{array}{l}\text { Agriculture and } \\
\text { forestry }\end{array}$ & 221.98 & 53.62 \\
\hline \multirow{2}{*}{$\begin{array}{c}\text { forestry } \\
\text { Other } \\
\text { non-construction land }\end{array}$} & 0 & \\
\hline & 414 & \\
\hline
\end{tabular}

Previously, villagers and collective group did not pay attention to agricultural development, as manufacturing brought greater economic profits. Faced with an increasingly polluted environment, villagers began to realize the importance of agriculture and ecological protection. $\mathrm{Pu}^{\prime}$ an village is currently experiencing an industrial transition toward a balanced economic structure, from being manufacturing-dominant to enabling comprehensive development. Based on the current master plan of Changzhou city, the municipal government has decided to build a beautiful village in $\mathrm{Pu}^{\prime}$ an, as a characteristic village exhibiting unique local culture and beautiful natural scenery. Therefore, figuring out how to revive agriculture while balancing the demands of environmental protection and rural development remains a key goal of rural planning. 


\subsection{Methodology and Data}

First, we used geographical information systems (GIS) to analyze the structure of land use in the village. Then, we made four assessments of fieldwork in January, April, August, and December 2016, to investigate seasonal features and identify the local natural resources. Thirdly, we applied a qualitative approach, involving semistructured focusgroup interviews (FDGs) with local villagers, leaders of collective groups, and immigrants. The interviews were carried out in August 2016 and lasted approximately $120 \mathrm{~min}$. The interviews focused on the rural culture, history, community identity, and "sense of place" of Pu'an village. The interviewees were asked four categories of questions, concerning the following: (1) the impression of the village in terms of culture, industry, and people; (2) the historical development of the village; (3) factors influencing the cultivation of rural culture; and (4) suggestions for development. The interviews were recorded and transcribed for analysis, with a manual identification of key words. From the interview analysis, we aimed to derive the "voice" of the local stakeholders, and integrate the master plan with the real requirements for implementation at the village level, so as to better analyze the rural plan from a cultural perspective [35].

\section{Results and Discussion}

\subsection{Two Factors Contributing to Identifying Bulrush as the Cultural Symbol}

A careful analysis of culture-led rural planning showed that it was different from industry-oriented planning, as it further utilizes the natural landscape and cultural resources related to the local identity of the village. From our findings, we can identify two factors contributing to identifying the bulrush as the cultural symbol of Pu'an.

The first factor is the natural landscape, which is a rich biological source of bulrush. We reclassified the four categories of rural land use into rural settlements, factories, open field, and rivers, using the GIS software. As Figure 2 shows, there were three types of mixed land use. The first was rural settlements along with a river and open field. The second one was factories close to rural settlements. The third one was a blend of open field and river. Obviously, the locations of rural settlements were scattered, and factories occupied the flat land. However, it was clear that the main landscape in the village was a large-scale cluster of green fields consisting of farmland, forestry, and wild grass. In addition, we carefully analyzed the biological resources in the open field in different seasons. According to our fieldwork, the water system in the village was accessible, with a large number of fishponds and reed ponds. In the open fields, the major aquatic plant is the bulrush, and the other featured plants are metasequoia, mao bamboo, reed, and Cinnamomum camphora. Bulrush was planted intentionally to be sold, as it has three economically valuable uses: as vegetables, medicines, and fillings. As regards its vegetable use, people can eat the bases of the young leaves and the apex of the rhizome. In terms of medical use, the pollen of the male flower is commonly known as pollen Typhae, which is used for stopping bleeding and removing blood stasis in Chinese traditional medicine. As regards its use as fillings, the female inflorescence can be used as a filling material for pillows and cushions; it has the characteristics of air permeability, moisture absorption, moisture resistance, deformation control, air purification, and durability. Aside from its economic benefits, this plant is beneficial for water purification [36]. It is common to see ducks in the ponds, sometimes even wild black water ducks, which are one of the nation's protected animals, in wild ponds. One of the older villagers reflected that when he was a child, he often saw egrets wading and feeding in the water. The incorporation of bulrush with the river can create a unique landscape that is quite different from the urban landscape.

The second factor is the important and intangible heritage of the bulrush craft. We investigated the tangible and intangible heritage in $\mathrm{Pu}^{\prime}$ an, and found that local villagers carried the tradition of bulrush craft. Bulrush craft originated with cultivation culture. In the historical records of $\mathrm{Pu}^{\prime}$ an village, it is stated that the name of the village was originally derived from the word for "bulrush," because in ancient times, the village was a low-lying marsh covered with bulrush. Pu'an in Chinese means "a shore side along bulrush ponds." 
Therefore, there is a long history of local villagers using bulrush in making shoes, fans, cushions, baskets, and other practical handicrafts. When we performed interviews with a group of elder villagers and the leaders of the collective group, they all recalled a memory of the bulrush swaying in the wind. One elderly man, Mr. He, said, "The original landscape where the industrial zone located on the west side of Liban road was a patch of bulrush. The river twisted and turned along with the lush bulrush, which was the most beautiful hometown scenery in my impression". Another older man, Mr. Xu, said, "Our younger generation lost the memory of bulrush and did not know why our village named as $\mathrm{Pu}$ 'an, as the bulrush was cut down and no one was willing to plant. I felt a pity to these changes." Although the young villagers are not familiar with the cultural dimension of the bulrush, the elder villagers carry strong nostalgia and a sense of identity related to the landscape of the bulrush. Mr. Lee, one of the leaders of the collective group, explained that, "The market of traditional bulrush product is limited and the profits of planting bulrush are quite low. Planting bulrush does not bring sufficient income to villagers, therefore villagers are not willing to plant bulrush. The craft of bulrush gradually lost. We need help to change the situation and to revive this local unique craft of bulrush weaving."

In addition to the intangible cultural resources, there are five categories of tangible resources, consisting of the Daliu temple; the characteristic water landscape; the ancient bridges, wells, and trees; the traditional rural architecture; and the ancestral hall, as shown in Figure 3. The Daliu temple was built in the Tang dynasty. The villagers stated that the ancient Daliu temple occupied almost the entire village. The remaining gate of the temple is in the southern part of village, and the remaining rear gate is in the northern part, thus stretching nearly three miles from north to south. The remaining structure occupies $168 \mathrm{~m}^{2}$, and is protected as a historic site at the city level as something that could be used to develop rural tourism.

Guided by the concept of the "beautiful village," the rural plan has identified the bulrush as the local cultural symbol, and attempts to combine the natural landscape and the cultural resources to cultivate a rural culture and improve the villagers' sense of identity.

\subsection{Framework of Bulrush-Centered Creative Industry in the Plan: Three Cameos}

The culture-led rural plan has designed an industrial framework that integrates agriculture and the creative industry via a bulrush-centered creative industry, as shown in Figure 4. In the framework, there are three cameos, consisting of one core industry and two extended industries. The core industry is the creative processing industry. The two extended industries are the creative planting industry and the creative tourism industry. Most importantly, the large-scale planting of bulrush is the foundation of agricultural development.

\subsubsection{Cameo 1: Core Industry with the Creative Processing of Bulrush}

$\mathrm{Pu}^{\prime}$ an's traditional processing industry was based on the bulrush, and involved purchasing, collecting, and weaving the plant. In our rural plan, the creative processing industry represents an updating of the traditional one, by which the latter is transformed to produce creative products. The plan outlines several potential paths the processing industry might take based on the multiple functions of the plant, such as the creation of household products via new weaving techniques, designing and creating cattail paintings and handicrafts that manifest a strong artistic sense of modeling and color, and making functional medicinal powders and teas.

It will be necessary to unite the villagers in order to plant the bulrush at a large scale, and build an industrial system based on bulrush processing. A creative processing industry demands innovative techniques in order to increase the value of the final products. In the long term, through the efforts of artists and other creative classes, the products should contribute to building a village brand in order to broaden the selling channels and improve competitiveness. 


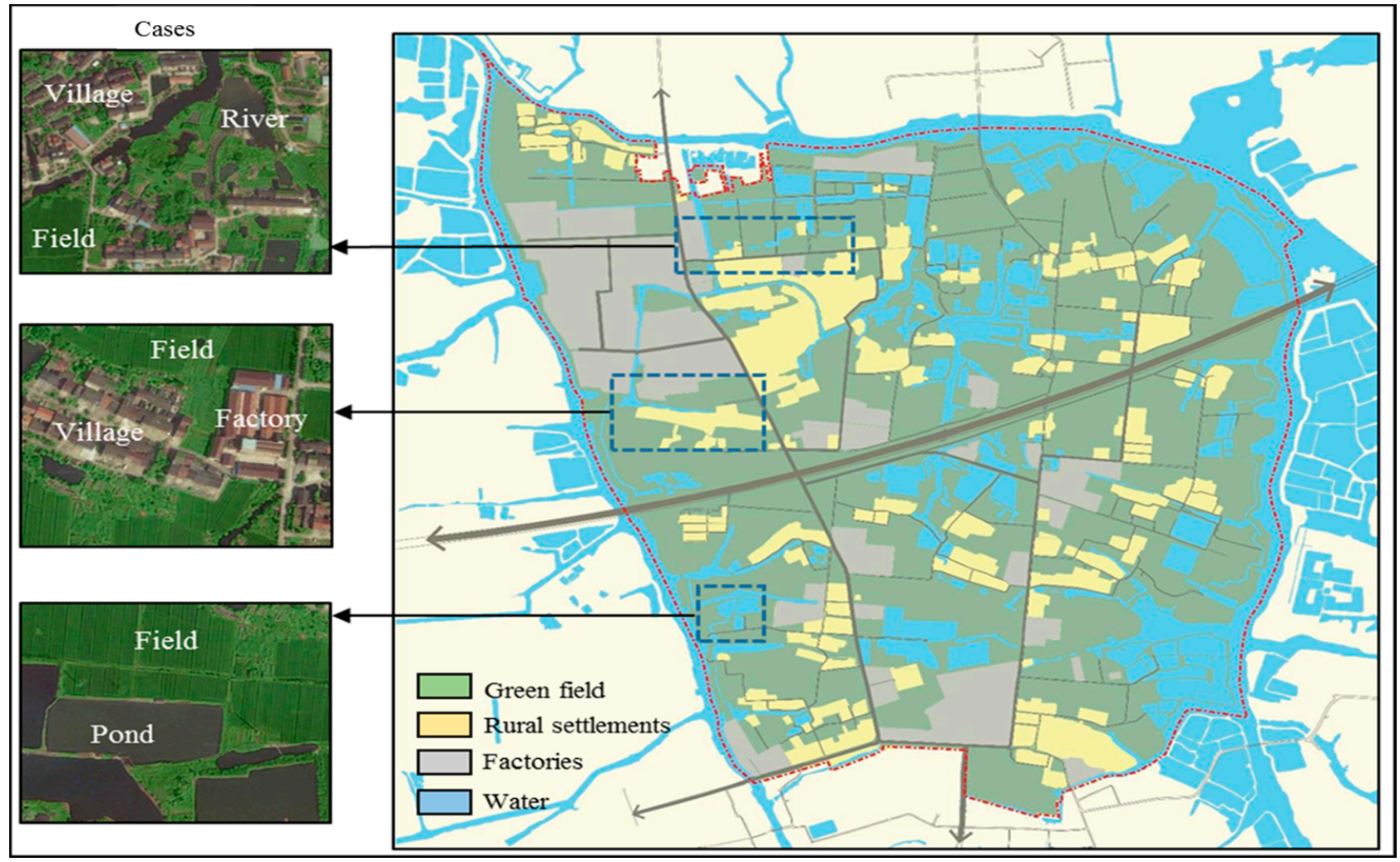

Figure 2. Difference types of landscapes in Pu'an village.

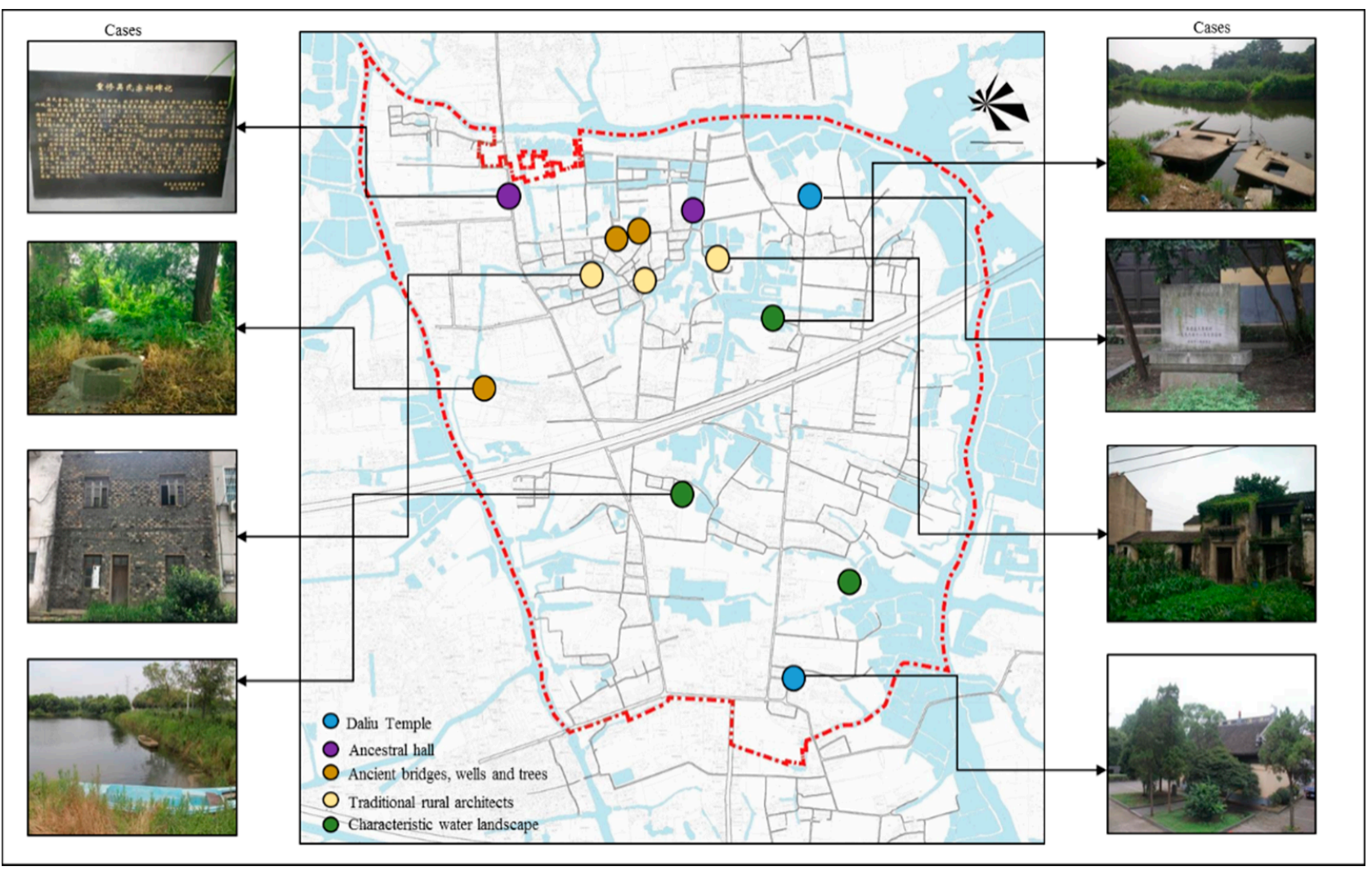

Figure 3. Tangible cultural resources in $\mathrm{Pu}$ 'an village. 


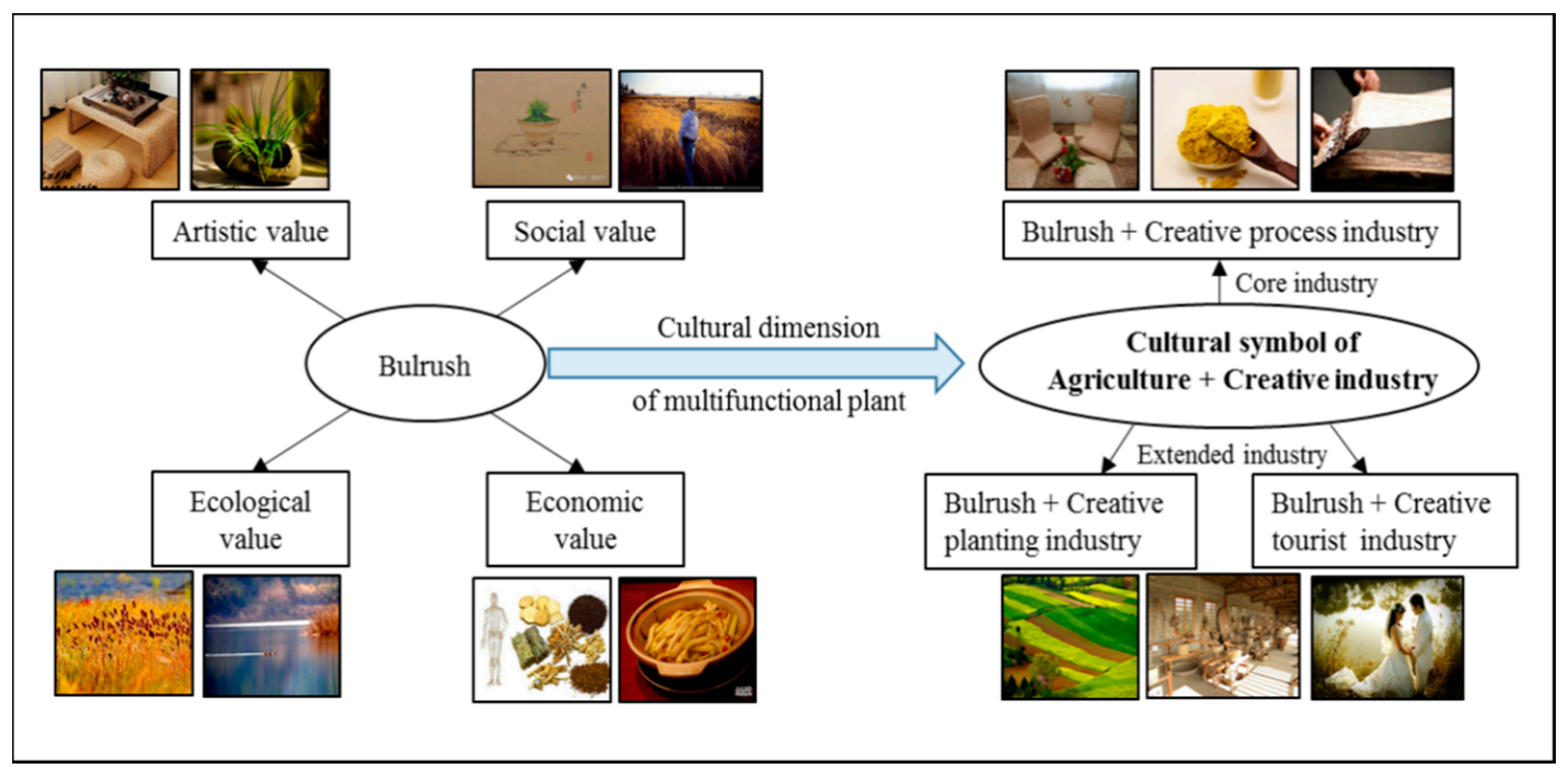

Figure 4. Multiple functions of the bulrush plant in the culture-led rural plan for Pu'an village.

\subsubsection{Cameo 2: Extended Industry with the Creative Planting of Bulrush}

Traditionally, bulrush is planted in ponds and wetlands without a specific technique. The creative planting of bulrush, however, involves a kind of ecological planting, based on the premises of protecting and improving the agricultural and ecological environment, following the laws of ecology and ecological economics, applying the methods of system engineering and modern science and technology, and the intensive managing of agricultural planting. Sometimes, bulrush will be planted in pots with special compost; this is referred to as potted cultivation.

In different seasons, the bulrush interacts differently with different animals. Creative planting aspires to reflect the natural beauty of the cohesion between human and nature, which will make people recall and pursue a better life. The designed landscape of the bulrush reflects the idea of comprehensive development, integrating ecological protection and economic development, as well as inheriting a culture of ruralism $[37,38]$.

\subsubsection{Cameo 3: Extended Industry with Creative Tourism Around the Bulrush}

With the development of the creative processing and planting of bulrush, Pu'an village has the potential to develop a creative tourism industry, combining production experience and the bulrush landscape. The rural plan aspires to a tourism industry built around leisure and relaxation. For example, the plan has designed several tourist routes along the rivers and ponds with bulrushes, for the purpose of natural sightseeing. Combined with the existing water systems and networks in Pu'an, some theme parks are planned for the promotion of the culture of the bulrush. Against the background of agricultural civilization, some existing farmland will be converted into experiential theme parks to allow tourists to experience bulrush planting or diversified agricultural activities.

Additionally, as the bulrush takes root in muddy water and yet remains straight and clean, poets eulogize that the bulrush bears the burden of a harsh environment, and it is depicted as having vigorous vitality in many Chinese poems. Combined with the cultural significance of the bulrush as a straight and pure spirit, bulrush farmland can offer beautiful scenery for wedding photography. The plan has tried to install photography as a basis to attract the youth, using the spectacle of the bulrush landscape. 


\subsection{Discussion}

Based on the analysis of interview data, we found local villagers were eager to shift their development mode toward sustainability. They recognized the importance of agriculture, and helped in trying to find solutions to improve the value of agricultural products. Within the culture-led plan, they found creative approaches to developing multifunctional agriculture with high economic, social, and spiritual values. The mixed framework of "bulrush + creative industry" emphasizes the importance of innovation and creativity in the development of agriculture. The unique features of the bulrush culture in $\mathrm{Pu}^{\prime}$ an village are valuable sources for this creativity. Therefore, it is important and necessary to identify local cultural resources in culture-led plans, in order to secure agricultural and further industrial development.

In addition, we saw that the functionality of the bulrush has been greatly expanded, in terms of its usage in artistic, ecological, economic, and social projects, enabled by the advanced processing techniques of softening and dyeing. Therefore, the designed industrial framework must investigate the functions of the bulrush from new perspectives. For example, the leaves of the bulrush are used for weaving, which is widely practiced in Pu'an. With advanced techniques to improve this artistic and economic value, some bulrush plants can be potted for ornamental and artistic purposes, with higher profits.

Finally, we recommended the participation of local villagers and outsiders, including urban tourists, creative classes, and entrepreneurs, in the policy. In the process of the implementation of the plan, the local government needs to consider the mechanisms by which internal and external forces will be united, so as to realize the industrial framework $[39,40]$.

\section{Conclusions}

There is more than one way to develop multifunctional agriculture in a peri-urban village. Our research provides a case study of combining agriculture and the creative industry, in order to develop the cultural dimension of multifunctional agriculture, which previous case-studies have insufficiently addressed. Pu'an village is a typical case, and is experiencing an industrial transition and a "culture turn" through its construction as a "beautiful village."

Through an analysis of the landscape and focus-group interviews, we have identified a cultural symbol in the agricultural plant of the bulrush due to both the natural landscape and locally cultural resources. First, changing the traditional perspective of manufacturingled plans, our culture-led plan redefines the main landscape of the village as a green field with rich biological resources of bulrush, which must be protected and improved. Secondly, reflecting local culture and history, the village's sense of place and identity are closely related to the bulrush, as the majority of local villagers have a strong emotional, nostalgic connection with the bulrush landscape, and a long tradition of bulrush craft. Therefore, the bulrush is identified as the cultural symbol of the village, essential to the agricultural development carried out by the rural plan that will result in a natural landscape with cultural resources.

Moreover, regarding bulrush as a precious resource for the creative industry, we have revealed the framework for a bulrush-centered creative industry, with one core leading industry and two extended industries. The core industry is the bulrush-processing industry, and the two extended industries are creative planting and creative tourism. This framework illustrates a possible approach to developing multi-industries, and incorporates cultureled agriculture to utilize the multiple functions of the bulrush for its artistic, ecological, economic, and social value.

Although the rural plan of Pu'an reports on the possibility of developing a culture-led agriculture, more studies are required in order to introduce more practices to classify the mechanism and strategy of branding, so as to attract urban inflows in agricultural development. 
Author Contributions: Conceptualization, W.L. and Y.Z.; methodology, W.L., Y.Z. and Z.Z.; formal analysis, W.L.; investigation, Y.Z. and Z.Z.; resources, Y.Z.; writing-original draft preparation, W.L.; writing-review and editing, W.L.; project administration, W.L.; funding acquisition, W.L. All authors have read and agreed to the published version of the manuscript.

Funding: This research was funded by National Natural Science Foundation of China, 41901192 and Fundamental Research Funds for the Central Universities,19lgpy46. The research was also supported by Innovation Group Project of Southern Marine Science and Engineering Guangdong Laboratory (Zhuhai).

Institutional Review Board Statement: Not applicable.

Informed Consent Statement: Informed consent was obtained from all subjects involved in the study.

Conflicts of Interest: The authors declare no conflict of interest.

\section{References}

1. Brinkley, C. Evaluating the Benefits of Peri-Urban Agriculture. J. Plan. Lit. 2012, 27, 259-269. [CrossRef]

2. Simon, D. Urban Environments: Issues on the Peri-Urban Fringe. In Annual Review of Environment and Resources; Annual Review: Palo Alto, CA, USA, 2008; Volume 33, pp. 167-185.

3. Pribadi, D.O.; Pauleit, S. The dynamics of peri-urban agriculture during rapid urbanization of Jabodetabek Metropolitan Area. Land Use Policy 2015, 48, 13-24. [CrossRef]

4. Marsden, T.; Sonnino, R. Rural development and the regional state: Denying multifunctional agriculture in the UK. J. Rural Stud. 2008, 24, 422-431. [CrossRef]

5. Yang, Z.S.; Cai, J.M.; Sliuzas, R. Agro-tourism enterprises as a form of multi-functional urban agriculture for peri-urban development in China. Habitat Int. 2010, 34, 374-385. [CrossRef]

6. Zasada, I. Multifunctional peri-urban agriculture-A review of societal demands and the provision of goods and services by farming. Land Use Policy 2011, 28, 639-648. [CrossRef]

7. James, S.W.; O'Neill, P.M. Planning for Peri-urban Agriculture: A geographically-specific, evidence-based approach from Sydney. Aust. Geogr. 2016, 47, 179-194. [CrossRef]

8. Yoshida, S.; Yagi, H.; Kiminami, A.; Garrod, G. Farm Diversification and Sustainability of Multifunctional Peri-Urban Agriculture: Entrepreneurial Attributes of Advanced Diversification in Japan. Sustainability 2019, 11, 2887. [CrossRef]

9. Ayambire, R.A.; Amponsah, O.; Peprah, C.; Takyi, S.A. A review of practices for sustaining urban and peri-urban agriculture: Implications for land use planning in rapidly urbanising Ghanaian cities. Land Use Policy 2019, 84, 260-277. [CrossRef]

10. Graefe, S.; Buerkert, A.; Schlecht, E. Trends and gaps in scholarly literature on urban and peri-urban agriculture. Nutr. Cycl. Agroecosyst. 2019, 115, 143-158. [CrossRef]

11. Duvernoy, I.; Zambon, I.; Sateriano, A.; Salvati, L. Pictures from the other side of the fringe: Urban growth and peri-urban agriculture in a post-industrial city (Toulouse, France). J. Rural Stud. 2018, 57, 25-35. [CrossRef]

12. Meraner, M.; Polling, B.; Finger, R. Diversification in peri-urban agriculture: A case study in the Ruhr metropolitan region. J. Land Use Sci. 2018, 13, 284-300. [CrossRef]

13. Renting, H.; Rossing, W.A.H.; Groot, J.C.J.; Van der Ploeg, J.D.; Laurent, C.; Perraud, D.; Stobbelaar, D.J.; Van Ittersum, M.K. Exploring multifunctional agriculture. A review of conceptual approaches and prospects for an integrative transitional framework. J. Environ. Manag. 2009, 90, S112-S123. [CrossRef]

14. Duxbury, N. Cultural and creative work in rural and remote areas: An emerging international conversation. Int. J. Cult. Policy 2020, 15. [CrossRef]

15. Xinhuanet. The Central Rural Work Conference Held in Beijing. Available online: http://www.gov.cn/jrzg/2013-01/31/content_ 2324293.htm (accessed on 26 February 2012).

16. Fang, C.; Wang, Z.; Liu, H. Beautiful China Initiative: Human-nature harmony theory, evaluation index system and application. J. Geogr. Sci. 2020, 30, 691-704. [CrossRef]

17. Chen, M.X.; Liang, L.W.; Wang, Z.B.; Zhang, W.Z.; Yu, J.H.; Liang, Y. Geographical thoughts on the relationship between `Beautiful China' and land spatial planning. J. Geogr. Sci. 2020, 30, 705-723. [CrossRef]

18. Boym, S. The Future of Nostalgia; Basic books: New York, NY, USA, 2001.

19. Wu, J. Landscape sustainability science: Ecosystem services and human well-being in changing landscapes. Landsc. Ecol. 2013, 28, 999-1023. [CrossRef]

20. Department of Culture, Media. and.Sport. Creative Industries Mapping Document; DCMS, Ed.; the British Council: London, UK, 2001.

21. Bell, D.; Jayne, M. The creative countryside: Policy and practice in the UK rural cultural economy. J. Rural Stud. 2010, 26, 209-218. [CrossRef]

22. Wilson, G.A. From productivism to post-productivism... and back again? Exploring the (un)changed natural and mental landscapes of European agriculture. Trans. Inst. Br. Geogr. 2001, 77-102. [CrossRef]

23. Wilson, G. Multifunctional 'quality' and rural community resilience. Trans. Inst. Br. Geogr. 2010, 35, 364-381. [CrossRef] 
24. McAuley, A.; Fillis, I. Careers and lifestyles of craft makers in the 21st century. Cult. Trends 2005, 139-156. [CrossRef]

25. Paulsen, K.E.; Staggs, K. Constraint and reproduction in an amateur craft institution: The conservative logic of the county fair. J. Poet. 2005, 134-155. [CrossRef]

26. Zivojinovic, I.; Weiss, G.; Wilding, M.; Wong, J.L.G.; Ludvig, A. Experiencing forest products-An innovation trend by rural entrepreneurs. Land Use Policy 2020, 94. [CrossRef]

27. Florida, R. The Rise of the Creatvie Class; Basic Books: New York, NY, USA, 2002.

28. Herslund, L. The Rural Creative Class: Counterurbanisation and Entrepreneurship in the Danish Countryside. Sociol. Rural. 2012, 52, 235-255. [CrossRef]

29. Hoey, B.A. From Pi to pie: Moral narratives of noneconomic migration and starting over in the postindustrial midwest. J. Contemp. Ethnogr. 2005, 34, 586-624. [CrossRef]

30. Richards, G. Creative tourism: Opportunities for smaller places? Tour. Manag. Stud. 2019, 15, 7-10. [CrossRef]

31. Gulumser, A.A.; Baycan-Levent, T.; Nijkamp, P. Measuring Regional Creative Capacity: A Literature Review for Rural-Specific Approaches. Eur. Plan. Stud. 2010, 18, 545-563. [CrossRef]

32. Townsend, L.; Wallace, C.; Fairhurst, G.; Anderson, A. Broadband and the creative industries in rural Scotland. J. Rural Stud. 2017, 54, 451-458. [CrossRef]

33. Balfour, B.; Fortunato, M.W.P.; Alter, T.R. The creative fire: An interactional framework for rural arts-based development. J. Rural Stud. 2018, 63, 229-239. [CrossRef]

34. Cunningham, S.; McCutcheon, M.; Hearn, G.; Ryan, M.D. 'Demand' for culture and 'allied' industries: Policy insights from multi-site creative economy research. Int. J. Cult. Policy 2020. [CrossRef]

35. Li, Y.H.; Westlund, H.; Zheng, X.Y.; Liu, Y.S. Bottom-up initiatives and revival in the face of rural decline: Case studies from China and Sweden. J. Rural Stud. 2016, 47, 506-513. [CrossRef]

36. Li, Y.; Zhang, J.; Zhang, C.L.; Wang, L.; Zhang, B. Biosorption of methylene blue from aqueous solution by softstem bulrush (Scirpus tabernaemontani Gmel.). J. Chem. Technol. Biotechnol. 2008, 83, 1639-1647. [CrossRef]

37. Bassett, D.L. Ruralism. Iowa Law Rev. 2003, 88, 273-342. [CrossRef]

38. Phillips, M.; Smith, D.P. Comparative ruralism and "opening new windows' on gentrification. Dialogues Hum. Geogr. 2018, 8, 51-58. [CrossRef]

39. Lee, A.H.J.; Wall, G.; Kovacs, J.F. Creative food clusters and rural development through place branding: Culinary tourism initiatives in Stratford and Muskoka, Ontario, Canada. J. Rural Stud. 2015, 39, 133-144. [CrossRef]

40. Li, W.; Zhang, Z.; Zhou, Y. Policy Strategies to Revive Rural Land in Peri-Metropolitan Towns: Resource Identification, Capitalization, and Financialization. Land 2021, 10, 132. [CrossRef] 